【モーニングセッション 8】

\title{
筋電 位波形に何を求めるのか?
}

\author{
森本茂 \\ (横浜国立大学)
}

筋線維の収縮を引き出すために興奮性膜は一過性 の陽性電位変化 $(=$ 活動電位) を示す .この活動電位 が容積導体中で構成する電流場(電位場)を体表面上 ／筋中から，すなわち細胞外導出・記録した現象が “筋電図”(表面筋電位/motor unit action potential : MUAP)である . 細胞外記録であるため, 膜電位と しての活動電位とは異なる . 筋の興奮を誘発する方 法によって，随意筋収縮時の筋電位と電気刺激等を 用いた誘発筋電位 (M-wave, H-wave, MEP：motor evoked potential)に分類される.筋電位は主に中枢 神経系興奮性の情報を定性的に表すと考えられてい るが，同時に骨格筋に筋電位の起源があることか ら，兴の波形には筋線維(群)情報も内在する.

\section{中枢神経系興奮性の指標}

活動する運動単位の数 (活動参加) と活動参加して いる運動単位の発火頻度が発揮筋力を調節してい る. 活動参加数と個々の運動単位の発火頻度が中枢 神経系の興奮性の指標となる.皮膚表面に装着した 電極には活動参加する個々の運動単位の発する MUAP が加算されて記録されることから，表面筋 電位波形の振幅, 積分值に活動運動単位の数が定性 的に反映されることになる。誘発電位の場合，ほぼ 同期して MUAP が発生するため, 乥の振幅から興
奮性の推定が可能となる . 振幅, 積分值からの興奮 性評価において，MUAP 波形が定常的であること が必要となる。

筋電位に内在する筋線維 群)の情報

MUAP 波形は, 神経一筋接合部で発生した活動 電位が筋一腱移行部まで伝導, 消滅するまでの過程 で次の事項が加味されつつ, 構成される.しかし, 導出方法によりMUAP 波形は大きく異なる．ここ では，単極導出を基本としている．

(1) 活動電位伝導速度

(2) 運動単位の筋中分布位置 (電極までの距離)

(3) 神経一筋接合部の分布範囲

(4) 筋線維長

(5) 導出方法

(6) 谷の他.

逆に, MUAP 波形を適当な方法で解析すること で, 特に解剖的な幾つかの事項(筋線維長, 神経一 筋接合部分布)の情報を引き出すことが可能となる． 表面電極で導出した MUAP 波形の解析から導き出 せる筋線維(群)の解剖的な情報について考察してみ たい. 次に, 表面導出 MUAP 波形の表面筋電位波 形への貢献，再構成も合わせて考察できればと考え ている． 